\title{
SAKRALITAS SAINS ISLAM: STUDI HISTORIS SAINS ISLAM ABAD PERTENGAHAN DAN SAINS MODERN
}

\author{
Fadhlu Rahman*, Anas Amarulloh** \\ *Program Studi Aqidah dan Filsafat Islam STFI Sadra, Jakarta \\ **Program Doktor Ilmu Pendidikan, Pascasarjana Universitas Negeri Yogyakarta, Yogyakarta
}

\begin{abstract}
The positivist science paradigm assumes that knowledge that cannot be verified empirically is not meant so that indirectly positive science reduces the knowledge system and limits it to something physical. The effects are knowledge of thirst for the search for true truth, because in its history naturally humans as seekers of knowledge can not be separated from the sacredness of the metaphysical status. Islamic science is the antithesis of the state of modern science. Islamic scientists underlie the process of searching for knowledge in the absolute self (God), so that science is considered as a system of revealing the veil of the knowledge of God while being able to become a Mecca of world knowledge. This paper seeks to show the possibilities of science potentially to return to eternal reality by showing the facts of the history of Islamic science based on historical methods in the Middle Age and making it a foothold of criticism on modern science. This is so that it can be concluded that science can potentially develop while returning to an eternal reality.
\end{abstract}

Keywords: Islamic science, sacrality, history.

\begin{abstract}
Abstrak
Paradigma sains positivis berasumsi bahwa pengetahuan yang tak dapat diverifikasi secara empiris tidak bermakna, sehingga secara tidak langsung sains positivis mereduksi sistem pengetahuan dan membatasinya pada sesuatu yang bersifat fisik. Dampaknya adalah pengetahuan haus akan pencarian kebenaran sejati, karena pada sejarahnya secara alami manusia sebagai pencari ilmu tak dapat terlepas dari kesakralan yang berstatus metafisik. Sains Islam menjadi antitesis dari keadaan sains modern. Para ilmuan Islam mendasari proses pencarian ilmunya pada diri yang absolut (Tuhan), sehingga sains dianggap sebagai sebuah sistem penyingkap tabir penghalang pengetahuan Tuhan sekaligus mampu menjadi kiblat pengetahuan sedunia. Tulisan ini berusaha menunjukan kemungkinan-kemungkinan sains secara potensial untuk kembali kepada realitas abadi dengan cara menunjukan fakta-fakta sejarah sains Islam berbasiskan metode historis pada abad pertengahan, serta menjadikannya pijakan kritik pada sains modern. Ini sehingga dapat disimpulkan bahwa sains secara potensial dapat berkembang sekaligus kembali pada realitas yang abadi.
\end{abstract}

Kata Kunci: Sains Islam, sakralitas, sejarah.

\section{PENDAHULUAN}

Sejak dahulu, sains dijadikan sebagai sebuah perantara untuk mengungkap realitas. Sains terus mengalami sebuah perkembangan yang sangat pesat. Hal ini menjadikan sains sebagai satu kesatuan sistem yang sangat kompleks dan tertata. Sistem sains terus berevolusi dan melahirkan berbagai cara serta teori dalam upaya mengungkap realitas. Sistem sains yang terus berkembang pada akhirnya tak dapat memungkiri akan adanya perubahan yang sangat signifikan dari cara pandangnya. Cara pandang tersebut berbasiskan akumulasi teori-teori dan karya-karya formal maupun nonformal. Secara historis tak dapat dipungkiri pula cara pandang sains terbentuk dari berbagai cara pandang lain akan terciptanya alam semesta. Ini artinya kita dapat menyimpulkan sains itu dibentuk oleh berbagai teori dan cara pandang, sehingga terakumulasi menjadi satu kesatuan sistem untuk menjawab realitas dunia.

Sains sebagai sebuah ilmu pengetahuan menghasilkan produk serta menjadi cermin atas kemajuan peradaban dunia. Hal ini menyebabkan sains menjadi tidak dapat

*Correspondance Author: gt630111@gmail.com

Article History | Submitted: April 7, 2019 | Accepted: June 23, 2019 | Published: July 1, 2019

How to Cite (APA $6^{\text {th }}$ Edition style):

Rahman, F., \& Amarulloh, A. (2019). Sakralitas Sains Islam: Studi Historis Sains Islam Abad Pertengahan dan

Sains Modern. JUSPI (Jurnal Sejarah Peradaban Islam), 3(2), 58-72. 
dipisahkan dari proses perkembangan peradaban ke arah yang lebih maju. Kemajuan tersebut merupakan bukti akan sebuah kekuatan pengetahuan sebagai tokoh utama dalam peradaban. Namun kemajuan tersebut jika tidak ditempatkan pada porsi yang tepat, justru akan berbalik menyerang manusia sebagai pelaku dari eksistensi sains itu sendiri. Hal ini terbukti dalam sejarah, sains mengalami sebuah pergeseran paradigma terhadap alam semesta dan mengakibatkan butanya sains terhadap hakikat dirinya sendiri.

Dimulai dari abad ketujuhbelas, sains modern menyatakan keterpisahannya dari hal yang bersifat sakral. Hal ini ditandai dengan pandangan modernisme yang memandang bahwa alam semesta seluruhnya ditentukan oleh manusia (Nasr, 2010, p. 182). Descartes diakui sebagai bapak filosof modern. Ia mendapatkan kesimpulan yang termuat dalam istilah Cogito Ergo Sum. Hasil perenungan ini menyatakan keterpisahan manusia dengan realitas yang bersifat sakral. Descartes menyatakan bahwa segala realitas dijelaskan oleh diri "aku yang berfikir". Ini sesuai dengan interpretasi yang diberikan oleh Anthony Kenny dalam buku The Rise of Modern Philosphy: "If I were not thinking, I would have no reason to believe that I existed; hence I am a substance whose whole essence is to think; being a body is no part of my essence" (Kenny, 2006, p. 36). Hal ini mengakibatkan seluruh realitas di luar dirinya menjadi tidak bisa dijelaskan tanpa dirinya yang berfikir termasuk Tuhan. Ini senada dengan komentar Nasr dalam buku In Search of the Sacred: "The dictum cogito ergo sum means" I think (cogito, je pense), therefore I am. The "I" and the "therefore" that comes from the "I" as ordinary human consciousness in this statement is the ultimate criterion that determines the truth and even being and existence (Nasr, 2010, p. 184). Komentar Nasr menjelaskan bahwa Descartes menjadikan kesadaran tentang aku sebagai pusat atau standar mutlak dari kebenaran. Ini membuat Tuhan kehilangan otoritasnya sebagai kebenaran mutlak, karena dirinya baru bisa dibenarkan oleh kesadaran "aku yang berfikir".

Setelah posisi manusia itu ditempatkan sebagai realitas absolut maka lahirlah aliran dan berbagai cara pandang lain yang terderivasi darinya seperti, humanisme, rasionalisme dan empirisme. Aliran-aliran tersebut kemudian membentuk cara berfikir dan cara pandang yang cenderung mereduksi realitas alam semesta menjadi partikular yang hanya dapat dijawab oleh matematika (Nasr, 1993, p. 5). Lahirlah pandangan positivis sebagai pemuas atas permasalahan tersebut.

Aliran positivis memandang bahwa alam semesta dapat dijawab oleh metodologi ilmiah yang telah disistematisasikan dan dibatasi penelusuran objeknya. Objek yang dapat dikaji hanya sebatas hal-hal yang dapat diverifikasi secara empiris saja, sehingga segala sesuatu yang tidak lolos dari syarat ini tidak dapat dikatakan ilmiah. Kemudian lahirlah istilah sains dan pseudo sains. Kedua istilah ini digunakan sebagai pembatas pengetahuan untuk dapat dikatakan ilmiah atau non-ilmiah. Pemisahan ini menimbulkan banyak kegalauan para saintis. Pasalnya manusia sebagai subjek peneliti tidak dapat menemukan kebenaran yang sejati dengan adanya pereduksian sistem alam dan pendikotomian pengetahuan (Nasr, 1993, p. 5).

Secara historis, kegalauan sains pernah diatasi oleh adanya sebuah keseimbangan antara kemajuan ilmu pengetahuan dengan kuatnya paradigma holistik. Abad pertengahan merupakan abad kemajuan sains di atas paradigma holistik. Seluruh 
pencarian kebenaran sains turtuju pada satu tujuan kebenaran yang utuh. Islam menjadi pelopor atas kemajuan tersebut, sehingga sains Islam menjadi kiblat pengetahuan bagi seluruh bangsa pada masa itu. Seluruh prestasi tersebut tidak lain disebabkan oleh ajaran Al-Qur'an yang memerintahkan umat muslim untuk mencari pengetahuan tanpa memandang sumber pengetahuan tersebut "The primordial character of revelation and its confidence that it was expressing the Truth at the hearth of all revelation, permitted Islam to absorb ideas from many sources, historically alien yet inwardly related to it" tulis Nasr dalam Science and Civiliazation in Islam (Nasr, 2001, p. 30). Hal ini menjadi poros dari pergerakan para saintis dan cendikiawan muslim dalam mengembangkan ilmu pengetahuan.

Kuatnya paradigma holistik tidak sama sekali menurunkan objektivitas sistem sains dalam islam pada masa itu. Hal ini dibuktikan dengan tetap otentiknya metode sains yang digunakan dalam penelusuran kebenaran ilmiah. "It may be said that its failure to give birth to modern science cannot be explained on the basis theory of the technical and narrowly scientific consideration" tulis Toby E. Huff dalam The Rise of Early Modern Science (Huff, 2003, p. 215).

Secara metode sains Islam tetap mengokohkan objektivitas ilmiah. Ini artinya secara potensial sains Islam tetap pada prosedur sains dalam mengembangkan penemuan-penemuan sains; meskipun paradigma yang digunakan adalah holistik. Bahkan E. Huff mengatakan sejatinya penemuan-penemuan yang diberikan oleh sains Islam memberikan jalan bagi kebanyakan saintis barat untuk sampai pada penemuan sainsnya, seperti Galileo dalam menemukan teori Free Fall yang dilatarbelakangi oleh teori gerak dinamis Ibnu Bajja. Tak hanya itu, bahkan Copernicus sebagai penemu teori heliosentris memiliki masalah yang terpecahkan oleh teori Jalal al-Din Tusi, seorang filosof sekaligus saintis Islam. Beberapa sektor pengetahuan penting seperti astronomi, geografi, optik, kedokteran, matematika, dan fisika dipelopori oleh teori yang diberikan para saintis muslim. Dengan demikian, secara metodologi sains Islam tetap pada prosedur sains tanpa menghilangkan paradigma holistik untuk mengungkap kebenaran ilmiah.

Dari fakta historis di atas, tulisan ini mencoba untuk manjawab pertanyaan: Mungkinkah sakralitas sains Islam diterapkan pada sains modern secara potensial dengan cara menerapkan paradigma holistik? Jika jawabannya positif, bagaimana kemungkinan-kemungkinan itu dapat diterapkan secara potensial pada sains modern dengan menggunakan pendekatan sejarah? Dari pertanyaan-pertanyaan di atas, tulisan ini mencoba untuk menjawabnya dengan cara menjelaskan: modernitas dan modernisme dan sejarah sains modern, makna sakralitas dan paradigma holistik, kemajuan dan sejarah sains Islam pada abad pertengahan.

\section{HASIL DAN PEMBAHASAN}

\section{Modernitas dan Paradigma Modernisme}

Dimulai dari penguraian makna modernitas dan modernisme sebagai dua kata yang memiliki makna berbeda. Modernitas diartikan sebagai keadaan zaman yang bersifat modern. Dalam kamus besar bahasa Indonesia disebut sebagai "kemodernan" secara filosofis hal ini tidak berkaitan dengan sikap pandang, melainkan hanya sebagai 
penamaan kondisi zaman yang dinilai penuh dengan teknologi. Sedangkan modernisme diartikan sebagai sebuah cara pandang bahwa manusia sebagai satu satunya realitas yang mutlak dan penentu daripada keberadaan penjelasan realitas lain. Nasr mengumpamakannya sebagai penempatan manusia pada tahta Tuhan "Removing God from the center of reality and putting man in His place” (Nasr, 2010, p. 209).

Modernisme secara historis dimulai pada abad Renaissance, yang ditandai dengan penggabungan mazhab epistemologi rasionalis dan empiris. Para tokoh dari kedua belah pihak tersebut antara lain: Descarates, Nicholas, Malebrance, Gottfield Wilhelm Leibniz, Benedict, Hobbes, John Locke dan David Hume. Kemudian diakhiri dengan penggabungan kedua metode tersebut oleh Immanuel Kant. Modernisme memandang bahwa manusia dan alam semesta terpisah dari sisi realitasnya. Keduanya memiliki jarak yang dibatasi oleh istilah subjek dan objek. Manusia dijadikan sebagai pusat peneliti dari realitas, artinya manusia dijadikan sebagai pusat penilaian dari realitas yang ada di luar dirinya. Cara pandang ini menggunakan rasionalitas sebagai potensi dasar dari justifikasi realitas empiris, dan pada puncak perkembangannya segala sesuatu yang empiris adalah satu-satunya realitas yang dinilai ada oleh paham ini. Cara pandang ini meyakini bahwa materi merupakan satu-satunya yang memiliki realitas objektif seperti yang dikatakan Hume dan Locke. Namun berbeda dengan Kant, ia berpendapat bahwa segala sesuatu termasuk hal yang bersifat materi tidak dapat diperoleh murni objektif, karena menurutnya manusia mempunyai beberapa kategori atau pengetahuan yang mempengaruhinya untuk mengetahui sesuatu secara hakiki (Maftukhin, 2010, pp. 188-189). Kategori tersebut diumpamakannya sebagai kaca mata hitam yang menghalangi penglihatan untuk melihat hal yang dilihatnya sebagaimana realitasnya.

Pada intinya modernisme memahami segala sesuatu yang diketahui manusia tidak lepas dari rasionalitas sebagai penentu semua realitas, meskipun masing-masing filosof yang mendirikan atau memajukan paham ini mempunyai perbedaan pendapat. Pada hakikatnya mereka mempunyai kesamaan untuk disatukan pada kategori pemegang paham modernisme.

\section{Sejarah Sains Modern}

Sains abad modern merupakan akumulasi pergerakan Revolusi Sains (Scientific Revolution) dan Abad Pencerahan (Enlightenment Age). Kedua hal ini menjadi cikal bakal bagi lahirnya sains modern. Dua moment ini tidak terlepas dari interaksi yang terjadi antara pengetahuan Barat dan Timur melalui penerjemahan yang terjadi di Spanyol, Sisilia dan Italia Utara. Penerjemahan tersebut ada dalam sebuah lembaga pendidikan yang dikuasai oleh Gereja pada masa itu, meskipun lembaga tersebut ada di bawah kekuasaan Gereja, lembaga tersebut diberi keluasan untuk mengembangkan dan mengatur aturannya secara independen (Huff, 2003, p. 180). Lembaga tersebut memfokuskan pengembangannya pada pengetahuan ilmiah, dan mendasari prinsipnya pada metode observasi dan rasional. Sehingga aturan yang diberikan oleh lembaga tersebut tidak sedikit berbasiskan prinsip dari tujuan tersebut. 
Dalam hasil penerjemahan tersebut kita dapat menemukan beberapa karya yang diterjemahkan diantaranya: Euclid dengan Element, Ptolemy dengan Almagest, Ibn alHaitham dengan Optic, al-Khwarizmi dengan al-Gebra, Ibn Sina Canon dan Galen serta Hippocrates dalam bidang kedokteran. Karya-karya tersebut dijadikan dasar kurikulum pada beberapa lembaga pendidikan masa itu, hingga akhirnya 2 dari 1200 lembaga pendidikan memperoleh kemajuan yang sangat pesat dalam pengetahuan ilmiah: Oxford dan Paris. Kurikulum tersebut dilandasi oleh 3 filsafat dasar yaitu: filsafat moral, filsafat alam, dan metafisik, namun filsafat alam dijadikan sebagai prinsip dasar bagi pengembangan pengetahuan pada masa itu (Huff, 2003, p. 181).

Sebelumnya dasar dari filsafat alam merujuk pada pemikiran Aristoteles yang termuat dalam beberapa karya pentingnya antara lain: On the Heaven, On Generation and Corruption, On the Soul, Metereology, and The Small Work of Natural Thing (Parva Naturilia), dan The History of Animal, The Part of Animal, The Generation of Animal. Seluruh karya Aristoteles tersebut dipelajari dan didukung oleh 7 subjek mata pelajaran (liberal arts), yang termuat dalam istilah trivium dan quadrivium. Trivium meliputi: tata bahasa (grammar) retorika dan logika, sedangkan quadrivium meliputi: aritmatika, geometri, astronomi dan musik. Pada abad keduabelas dan ketigabelas mata pelajaran yang terliputi oleh quadrivium mengalami perkembangan yang sangat pesat sekaligus menyatu dengan filsafat alam (natural philosophy) (Huff, 2003, p. 181).

Seiring dengan perkembangan itu, peletakan kurikulum filsafat alam berubah setelah ditemukannya beberapa karya yang bersifat kontra terhadap aliran Aristotelian. Hal ini dapat dibuktikan dengan penemuan beberapa karya pada masa itu antara lain: The Lives of the Philosopher oleh Diogenes Laertius dan On the Nature of the God oleh Cicero (Henry, 2003, p. 11). Kedua karya ini membuka cara pandang baru terhadap alam semesta dengan cara mengkritik aliran Aristoteles. Selain itu penghidupan kembali aliran skeptisisme kuno juga memberikan andil besar bagi perubahan kurikulum filsafat alam pada masa itu, sehingga filsafat alam mulai mendapatkan posisi serta cara pandang baru dalam memaknai alam semesta dan mendapatkan pengetahuan mengenai alam semesta.

Keadaan tersebut menjadi basis kemunculan Abad Pembaharuan (Renaissance) dan akhirnya usaha saintifik lebih mengarah pada metode observasional dan rasional, sehingga munculah keadaan baru yang disebut sebagai The Age of Reason atau Enlightenment Age sebagai sebuah pembaharuan cara pandang manusia menjadi lebih bebas dan rasional serta menempatkan manusia sebagai ukuran dari alam semesta begitu kata Protagoras yang dinilai sebagai inspirator masa itu. Abad ini sebelumnya ditandai dengan loncatan paradigma yang sangat jauh. Loncatan tersebut diawali dengan penemuan Nicholas Copernicus atas teori heliosentris pada tahun 1523 dalam De Revolutionibus Orbium Coelestium yang sebelumnya dikuasai penuh oleh pandangan Geosentris's Ptolemeus dalam Almagest. Paradigma dan temuan Copernicus menjelaskan bahwa matahari sejatinya menjadi pusat dari tata surya, sedangkan Ptolemeus menyatakan bahwa bumi yang menjadi pusat dari tata surya.

Penemuan Copernicus diakui sebagai perubahan yang cukup radikal dalam kancah sains, dan budaya. Pertimbangan atas hal ini tidak hanya terdapat pada teorinya yang berlawanan dengan kitab Bible, tapi juga melawan filsafat alam Aristoteles yang 
pada masa itu dijadikan sebagai salah satu standar dari filsafat alam. Meski demikian Copernicus tidak sepenuhnya dinilai sebagai orang yang sempurna menemukan teori tersebut, karena menurut ilmuan setelahnya, ia belum bisa menunjukan argumentasi filosofis atas penemuannya, ia dinilai sekadar menggunakan matematika dalam menjawab persoalan teorinya (Henry, 2003, p. 17). Meski demikian ia pantas dijadikan sebagai revolusioner dan inspirator bagi ilmuan-ilmuan astronomi setelahnya dalam mengembangkan teori heliosentris. Pasalnya semua ilmuan astronomi setelahnya dinilai oleh sejarawan tidak mampu untuk mengembangkan teori-teorinya tanpa penemuan teori heliosentris Copernicus. "Moreover those who followed Copernicus, for example, Kepler, Galileo, and later Newton could not have achieved what they did without the switch from the geosentric to a heliocentric universe", tulis Toby E. Huff (Huff, 2003, p. 327).

Sains modern mulai menunjukan karakternya atas penemuan Copernicus, yang memberikan andil besar bagi perubahan cara pandang ilmuan-ilmuan pada masa itu. Setelah teori heliosentris ditemukan, otoritas pemerintahan mengalami perubahan. Ada dua perubahan yang cukup signifikan dalam perkembangan sains dan hubungannya dengan pemerintahan pada masa itu, sehingga hal ini dapat dijadikan prinsip dasar untuk membedakan sains di Abad Pertengahan dengan sains modern. Pertama, perbedaan tersebut dapat dilihat dari berkurangnya otoritas Gereja. Perubahan otoritas Gereja yang berkurang memberikan keleluasaan bagi sains untuk berkembang dan mendapatkan posisi khusus dalam pemerintahan. Hal ini ditunjukan oleh fakta bahwa penemuan-penemuan sains yang bersifat menentang otoritas Gereja tidak mendapatkan hukuman sebagaimana yang terjadi pada Abad Pertengahan, dan pihak Gereja memberikan ruang untuk mendapatkan kritik atas doktrin-doktrinnya. Kedua, perbedaannya dapat dilihat dari peningkatan otoritas sains dengan salah satu bukti pempublikasian karya Copernicus pada tahun 1543 yang sebelumnya menggunakan Bible sebagai satu-satunya standar hukum teori kosmologi (Russel, 1945, p. 492). Keadaan demikian memberikan peluang sains untuk mendapatkan dimensi dan status ontologi baru bagi keberadaannya sebagai sistem ilmu pengetahuan dalam pemerintahan.

Tak lama setelah itu, pada abad kelimabelas sains mengalami pengorganisasian kembali, artinya sains mengalami revisi. Manusia dan metode menjadi dua hal yang dipertimbangkan untuk direvisi (Boas, 1962, p. 238). Pada abad tersebut universitas merupakan objek yang dijadikan sebagai perantara untuk pengorganisasian kembali. Pada aspek manusia ditetapkan beberapa kurikulum standar yang menjadikan manusia dikatakan sebagai seorang saintis diantaranya kemampuan matematika, yang sebelumnya sudah beralih dari Euclid kepada Archimedes sebagai basis dari aliran matematika (Boas, 1962, p. 240). Adapun pada aspek metode, Francis Bacon dipertimbangkan sebagai orang yang memberi pengaruh besar pada revolusi metode sains masa itu. Ketika filsafat alam Aristoteles ditinggalkan, Bacon datang sebagai penghidup kembali filsafat alam Aristoteles dengan beberapa modifikasi. Kehadirannya tidak hanya mengkritik para pelajar pada masa itu melainkan memberikan kontribusi besar pada filsafat alam yang setidaknya pada dua hal: Pertama, ia mampu mentranformasikan filasafat kontemplatif menuju filsafat praktis yang berfokus pada pertanyaan filosofis filsafat alam (science). Kedua, ia diakui sebagai penemu atas rumus yang dijadikan syarat bagi metode induktif sains modern. Novum Organum merupakan 
karyanya yang berkontribusi pada metodologi sains, karya ini mendemonstrasikan, bagaimana cara memproses fakta menjadi sebuah teori umum sehingga sebuah hukum partikular mendapatkan sebuah penilaian universal (Boas, 1962, p. 255). Kontribusinya kemudian diakui di abad kedelapanbelas dan disandingkan dengan Newton sebagai salah seorang yang memberikan kontribusi besar pada sains modern.

Fakta historis tersebut dapat membuktikan bahwa sejarah sains modern didasari oleh keadaan Barat yang setidaknya terdiri dua masa kebangkitan. Dua keadaan tersebut adalah Abad Pencerahan (Enlightenment Age atau Age of Reason) dan Revolusi Sains (Scientific Revolution). Dua masa ini saling bergantung satu sama lain, bahkan beberapa keadaan ada pada waktu yang sama seperti Reformasi Gereja. Dua keadaan ini terangkum oleh Abad Renaissance yang tidak terlepas dari peranan ilmuan-ilmuan terdahulu baik Yunani maupun Islam melalui proses penerjemahan. Namun dalam proses perkembangannya, sains modern mulai melepaskan pengetahuan ilmiah dari kesakralan. Hal ini jelas ditandai dengan karya Cicero dan Laertius yang mengkritik terhadap karya-karya Aristoteles, sehingga membuat kurikulum dan cara pandang Barat terhadap alam semesta beralih ke metode observational.

\section{Sakralitas dan Paradigma Holistik}

Sakralitas secara bahasa dikategorikan sebagai kata benda yang bersumber dari kata sifat yaitu sakral. Sakral dalam bahasa Inggris "sacred" yang artinya sesuatu yang bersumber dari realitas ketuhanan. Lebih jauh hal ini dijelaskan Nasr sebagai realitas ketuhanan yang memanifestasikan atau mewujudkan dirinya kepada wujud ciptaannya (Nasr, 2010, p. 203). Kita dapat menemukan benda atau ciptaan-ciptaannya yang bersifat sakral seperti penamaan terhadap kota Yerussalem sebagai Bayt al-Muqoddas (Muqoddas dalam bahasa Arab berarti sakral) hal ini dinamakan demikian karena hubungannya dengan realitas yang bersifat sakral.

Namun di Barat baru-baru ini istilah tersebut sudah terhapus dari jejak makna aslinya. Istilah tersebut digunakan secara metaforis salah satunya ketika seseorang mengatakan "Hal ini adalah sakral buatku" dengan maksud mengunjungi rumah temannya setiap hari Minggu pagi. Kehilangan makna asli tersebut tentunya menimbulkan kegamangan dalam menggunakan istilah tersebut, yang akhirnya originalitasnya menjadi hilang. Penggunaan istilah tersebut di Barat sangat sekali disayangkan, pasalnya istilah tersebut memiliki konotasi yang dijustifikasi sebagai hal yang tidak mungkin dicapai oleh manusia (transenden) dan dianggap sebagai aktivitas mental belaka bukan sebuah realitas hakiki sekaligus dianggap pengetahuan yang ada setelah pengetahuan fisik (metafisik) sedangkan pengetahuan tersebut (metafisik) merupakan hakikat dari segala pengetahuan lain sebagaimana yang dinyatakan Nasr dalam Knowledge and The Sacred:

"This term possesses certain unfortunate connotations because, first of all, the prefix meta does imply transcendence but not immanence and also it connotes a form of knowledge or science that comes after physics whereas metaphysics is the primary and fundamental science or wisdom which comes before and contains the principles of all the sciences" (Nasr, 1989, p. 120).

Dari segi bahasa permasalahan sakralitas terlihat pada sisi penggunaan makna dan esensi dari maknanya. Makna asli yang terkandung oleh kata sakral baru bisa 
terakses secara penuh ketika mengambil makna tersebut dari sudut pandang kaum tradisionalis. Para tradisionalis menjelaskan bahwa bahasa-bahasa metafisik memiliki keterpisahan dari segi makna dengan bahasa konvensional, dan memiliki pesan khusus yang baru bisa disampaikan dengan pemahaman tradisionalis. Pasalnya kata-kata tersebut dikembangkan maknanya oleh para ahli metafisik dan orang-orang suci (Nasr, 2007, p. 133). Makna yang terkandung oleh kata tersebut bisa dimaknai secara utuh ketika menggunakan sudut pandang tradisional. Dengan demikian penggunaan makna sakral harus ditempatkan pada sistem paradigma yang dapat memaknai kata tersebut secara utuh sehingga kita dapat menggunakan kata tersebut dan menerapkannya pada kata lain secara tepat.

Penggunaan makna sakral secara proporsional memberikan jalan bagi sikap cara pandang holistis pada alam semesta, karena sakralitas merupakan unsur yang terkandung pada cara pandang holistis. Holistis bermakna bahwa segala bentuk ciptaan alam semesta dipandang sebagai satu kesatuan utuh (unity) dari pada satuan terpisah (Capra, 1996, p. 6). Prinsip bahwa segala hal merupakan satu kesatuan itu telah dialami oleh Fritjof Capra. Pengalamannya menyimpulkan bahwa setiap masalah yang ada tidak dapat dipisahkan dari masalah lainnya: "The more we study the major problems of our time, the more we come to realize that they cannot be understood in isolation. They are systemic problem, which means that they are interconnected and interdependent" (Capra, 1996, p. 6). Satu kesatuan tersebut bersumber pada Tuhan sebagai realitas abadi dan penyebab bagi munculnya realitas lain. Dalam tradisi timur realitas abadi bisa disebut Brahman (Hinduisme), Dharmakaya (Budhisme), dan Tao (Taoisme). Capra menjelaskan lebih dalam mengenai hal ini dalam The Tao of Physic:

"The most important characteristic of the Eastern world view one could almost say the essence of it is the awareness of the unity and mutual interrelation of all things and events, the experience of all phenomena in the world as manifestations of a basic oneness. All things are seen as interdependent and inseparable parts of this cosmic whole; as different manifestations of the same ultimate reality" (Capra, 1975, p. 130).

Dapat disimpulkan bahwa paradigma holistik berpegang teguh pada kesadaran bahwa alam semesta merupakan satu kesatuan yang bersumber dari satu realitas hakiki. Mulla Sadra dalam Mazahir al-Ilahiyah menjelaskan mengenai realitas hakiki adalah yang dimaknai sebagai Tuhan yang Maha Esa. Lebih jauh ia menjelaskan bahwa realitas Tuhan merupakan realitas yang sempurna dan sederhana. Wujudnya merupakan penjelas bagi wujud lain. Alam semesta sebagai manifestasinya bersumber dari kemestian wujudnya sebagai wajib al-wujud yang tidak membutuhkan sebab lain bagi keberadaan dirinya (Shirazi, 1999, p. 15). Oleh karenanya paradigma holistik mengantarkan kita pada pemahaman bahwa seluruh alam semesta bersumber dari satu realitas absolut atau realitas ketuhanan (sakral) yang tidak membutuhkan sebab lain sekaligus memandang bahwa alam semesta berada pada satu kesatuan wujud yang saling bergantung dan memberikan pengaruh satu sama lain sebagai manifestasi wujud absolut.

\section{Kemajuan, Identitas, dan Sejarah Sains Islam pada Abad Pertengahan}

Sebelum membahas mengenai kemajuan peradaban Islam pada abad pertengahan, kiranya kita perlu mengetahui proses perubahan cara pandang manusia 
terhadap alam semesta sebelum Islam. Hal ini dimaksudkan agar dapat mengetahui proses kemajuan sains pada masa kejayaan Islam dengan melihat signifikansi perubahan cara pandang dan pembuktian empiris terhadap alam semesta. Ilmu pengetahuan yang khusus membahas mengenai sejarah, struktur dan cara kerja alam semesta adalah kosmologi. Manusia sebelum berfikir lebih modern mengenai alam semesta bermula berpegang teguh pada pandangan mistik kuno. Pandangan ini berawal di Babilonia dan Mesopotamia. Pada masanya alam semesta (universe) dianggap sebagai box, dan bumi (earth) terletak di bawahnya sedangkan gunung dianggap sebagai penyangga yang terletak di setiap penjuru alam semesta (Turner, 1995, p. 36). Tak lama kemudian perkembangan pengetahuan kosmologi berkembang pesat setelah jatuh ke tangan filosof. Sebelum itu sains dan filsafat diperkirakan berkembang secara bersamaan setelah ditemukannya seni menulis oleh Mesir Kuno pada tahun 4000 SM dan tak lama kemudian disusul oleh Mesopotamia.

Meskipun Mesir dan Mesopotamia menjadi cikal bakal perkembangan intelektual manusia, kedua daerah tersebut belum mencapai perkembangan yang klimaks sebelum disempurnakan oleh Yunani dengan berkembangnya tradisi intelektual yang ditandai dengan filsafat dan matematika (Russel, 1945, p. 3). Thales yang secara historis diakui sebagai filosof pertama menganggap alam semesta sebagai sebuah kesatuan yang solid, sedangkan Anaximander menganggap alam semesta muncul akibat kelembaban yang diuapkan oleh matahari. Perkembangan pemikiran alam semesta berlanjut hingga jatuh ke tangan Plato dan Phytagoras, keduanya menganggap alam semesta dikendalikan oleh Tuhan sebagai realitas hakiki, namun tak lama kemudian ditolak oleh pandangan Anaxagoras dengan menganggap bahwa pergerakan alam semesta bukan diakibatkan oleh Tuhan melainkan jiwa. Perdebatan pemikiran ini berlangsung lama hingga akhirnya puncak pemikiran Yunani mengenai kosmologi jatuh ke tangan Aristoteles. Ia berpandangan bahwa alam semesta digerakan oleh sebuah kausa prima yang tak digerakan oleh kausa lain. Di Timur, Cina mengembangkan pemikiran kosmologinya dengan konsep Taoisme. Ajaran tersebut berpandangan bahwa alam semesta merupakan suatu kesatuan yang seimbang di bawah simbol Yin dan Yang.

Saatnya sains mengalami sebuah perubahan yang signifikan dari cara pandangnya terhadap alam semesta. Ini terbuka ketika Ptolemy seorang astrnomer Hellenis mengembangkan konsep pergerakan planet Aristoteles dan Neoplatonis, namun estafet kemajuan pemikiran mengenai konsep tersebut secara penuh baru berkembang setelah jatuh ketangan masyarakat Islam. Hal ini terbukti dengan skema kosmologi yang sangat kompleks dan modern dalam memberikan fakta serta data empiris mengenai kejadian di luar angkasa seperti perputaran planet. Ini senada dengan penjelasan Howard R. Turner dalam Science in Medieval Islam: "Muslim were beginning to develop cosmological schemes that were sufficiently complex and sophisticated to include as empirical fact celestial happening that could actually be observed, such as details of the variations in planetary path" (Turner, 1995, p. 38). Sebelum pembuktian ke tahap ini bangsa Kristen Eropa sudah lebih dulu mengembangkannya ke tahap spekulasi rasional, namun hal tersebut belum terbukti dengan data empiris. Sehingga puncak klimaks kemajuan teori mengenai alam semesta pada Abad Pertengahan baru terbukti secara utuh di bawah peranan sains Islam, dengan bukti kelengkapan data-data empiris serta nalar rasional dalam memandang alam semesta. 
Di balik itu semua, Islam dengan ajarannya yang terbuka untuk menyerap ilmuilmu Yunani dan bangsa Timur lain membuatnya kaya akan cara pandang terhadap alam semesta. Poros usaha saintifik tidak lepas dari paradigma ketuhanan sebagai pandangan sejatinya, dan gradasi unitas sebagai konsep pokok ketuhanannya. Seluruh usaha serta tujuannya berpuncak pada satu harapan untuk mencapai kebenaran ilahiah sebagai manifestasi dari seluruh entitas alam semesta (Nasr, 2001, pp. 21, 22, 30). Ini kemudian Capra sebut sebagai paradigma holistik di mana sains dianggap sebagai sebuah kesatuan utuh. Seluruh sains memiliki interkoneksi yang kuat dan tidak terlepas dari prinsip kesatuan sumber yang diklaim sebagai Tuhan (Capra, 1996, p. 6). Di bawah naungan inilah sains Islam bergerak dan menunjukan identitas aslinya sebagai sains.

Permulaan sains Islam berawal dari penerjemahan besar-besaran yang terjadi di Gudinshapur. Hal ini terjadi ketika kota tersebut ditaklukan oleh bangsa Arab pada tahun $638 \mathrm{M}$ Penerjemahan tersebut kemudian membuat Islam kaya akan ilmu pengetahuan, sehingga menjadi pusat bagi penyebaran pengetahuan Yunani dan pengetahuan lain. Penerjemahan yang dilakukan tidak bisa terlepas dari peran para cendikiawan serta ilmuan Yahudi maupun Nasrani seperti Hunain bin Ishaq sebagai salah satu penerjemah Kristen terbaik pada masa kebangkitan sains Islam. Dua abad setelah program penerjemahan, sains Islam mampu menerjemahkan bahkan merevisi beberapa karya-karya penting bagi kemajuan peradaban dunia seperti karya: Plato, Aristotles, Euclid, Archimedes, Hippocrates, Galen, Ptolemy dan lain-lain. Keberhasilan atas penerjemahan tersebut akhirnya menggemilangkan muslim pada beberapa sektor ilmu pengetahuan diantaranya: astronomi, matematika, fisika, kimia dan kedokteran.

\section{Kemajuan Sains Islam di Bidang Astronomi dan Matematika}

Kemajuan di bidang astronomi dan matematika dalam Islam tidak terlepas dari peranan bangsa terdahulu diantaranya: Yunani, Sassanian dan India. Tujuan dari para ilmuan muslim dalam bidang astronomi adalah mengungkap tabir pergerakan bendabenda langit dengan sistem matematika (Turner, 1995, pp. 58, 61). Dari tujuan astronominya kita dapat menemukan salah satu dari tujuan matematikanya yaitu sebagai sistem untuk menjawab persoalan benda-benda langit. Secara historis semua usaha saintifik Islam dalam bidang astronomi dan matematika dikerahkan untuk mengembangkan konsep-konsep yang telah ditemukan oleh bangsa India, Sassanian dan Yunani. Tentu dalam proses pengembangan konsep-konsep tersebut saintis Islam banyak menemukan teori-teori baru bahkan pada akhir pengembangan di bidang astronomi, Islam lebih fokus pada kritik terhadap berbagai aspek dari teori Ptolemy yang diakui sebagai founder dari berbagai teori gerak planet.

Islam pertama mendapatkan pengetahuan secara mendalam tentang astronomi dan matematika melalui sekolah dan karya-karya ilmuan India yang sejatinya sudah hasil pengembangan dari teori-teori Yunani dan Babilonia. Tak lama kemudian dipengaruhi langsung oleh teori-teori yang dikembangkan oleh bangsa Yunani di bawah penemuan-penemuan Ptolemy khususnya dalam bidang Astronomi, dan Euclid di bidang matematika. Kedua gerbang ini yang menjadi jalan bagi saintis muslim untuk melakukan pengembangan, pengkoreksian dan penemuan dalam bidang astronomi dan matematika. 
Kedua gerbang tersebut melahirkan tokoh-tokoh berpengaruh dalam bidang astronomi dan matematika seperti Habbas al-Hasib penyusun Table Ma'munic. AlKhawarizmi sebagai penggabung dua tradisi matematika antara Yunani dan India dalam karyanya The Book of Summary in the Process of Calculation for Compulsion and Equation, selain itu ia juga banyak menghasilkan karya di bidang astronomi, al-Fraghani (al-Fragnus) pencetus karya terkenal The Element of Astronomi dan al-Mahani sebagai pengembang teori Aljabar sekaligus terkenal atas komentarnya terhadap permasalahan karya Archimedes (Nasr, 2001, pp. 149, 169).

Pada abad kesepuluh dalam bidang Astronomi dilanjutkan oleh Abu Sahl al-Kuhi dan Abd al-Rahman al-Sufi dengan karya monumentalnya Figure of the Stars. Karya tersebut dikategorikan sebagai masterpiece dari tiga karya peneliti bintang dalam Islam oleh sejarawan sains George Sarton. Sedangkan dalam bidang matematika diwakili oleh Thabit Ibn Qurra sebagai penerjemah bebarapa karya penting Archimedes dan Nichomachus seperti: Connic of Apollonius dan Introduction to Arithmetic. Ibn Sina meski dikategorikan sebagai filosof, ia juga berhak untuk disebut sebagai matematikawan dengan bukti beberapa karyanya dalam menyelesaikan masalah angka dan penentuan terhadap jarak radius bumi (Nasr, 2001, pp. 149, 170).

Pada abad kesebelas, Zarqali seorang ilmuan astronomi Spanyol menemukan instrumen astronomi baru yang dinamakan Saqifah yang kemudian sangat dikenal luas oleh para ilmuan. Adapun di bidang Matematika al-Gebra Umar Khayyam dikategorikan sebagai salah satu karya monumental pada Abad Pertengahan. Kemudian abad keduabelas dalam bidang astronomi, tradisi mengkritik karya Ptolemy mulai mencuat. Jabir Ibn Aflah (Geber) mulai mengkritik karya-karya Ptolemy, dan dilanjutkan oleh filosof Muslim Ibn Bajja dan Ibn Tufail dengan menggunakan konsep kosmologi Aristoteles. The School of Maragha (sekolah Maragha) yang di pimpin oleh astronom Nasir al-Din al-Tusi banyak memberikan kritik pada konsep Ptolemy. Kritikan tersebut tidak berujung pada pengkoreksian tanpa solusi. Nasir al-Din Tusi menawarkan konsep baru dalam model sistem gerak planet, namun konsep tersebut baru terlesaikan secara utuh ketika dilanjutkan oleh muridnya Qutb al-Din al-Shirazy. Ibn Shatir pada abad keempatbelas datang sebagai orang yang menyelesaikan teori lunar model dengan menggunakan dasar teori Tusi dan Ptolemy. Ia berperan untuk memberikan gambaran pada teori lunar system Copernicus menurut Seyyed Hossein Nasr, sebagaimana yang ia nyatakan dalam Science and Civilization in Islam: "The lunar theory proposed two centuries later by Copernicus is the same as that of Ibn al-Shitir, and it seems that Copernicus was somehow acquainted with this late development of Islamic astronomy, perhaps through a Byzantine translation" (Nasr, 2001, pp. 171, 173). Namun jika hal ini dipertemukan dengan hasil penelitian George Saliba manjadi tidak dapat dibenarkan oleh peneliti lain, diantaranya Victor Robert, Edward Kennedy, dan Fuad Abduh dengan cara mengukur parameter numeris kedua karya astronomi tersebut (Ibn Shittir dan Copernicus): 


\begin{abstract}
"In the years that followed, Victor Roberts, Edward Kennedy, and Fuad Abbud, either independently or jointly managed to publish notices about Ibn al-Shatir's remaining models and about the possible connection with Copernicus. Abbud went as far as to compare the numerical parameters of Ibn al-Shatir's Zlj and Copernicus's De Revolutionibus, and concluded that although the tables of Ibn al-Shatir were similar to those of Copernicus, the latter's were not a direct copy of the first, despite the fact that they both deviated in the same direction from Ptolemy's tables" (Saliba, 1994, p. $113)$.
\end{abstract}

Keduanya memiliki kesimpulan berbeda dalam menyalin atau tidak menyalinnya Copernicus pada tabel yang dibuat oleh Ibn Shittir. Namun Dari kedua informasi tersebut dapat disimpulkan bahwa kedua informasi tersebut tetap memiliki kesamaan pada kenyataan bahwa Copernicus dan Ibn-Shittir memiliki tabel yang sama dalam teori sistem lunar. Jika dilihat secara historis Ibn Shittir hidup di zaman sebelum Copernicus, maka teori mengenai sistem lunar pertama ditemukan oleh Ibn Shittir, kemudian Copernicus. Sedangkan dalam bidang matematika Ibn Banna al-Marrakushi membuat pendekatan baru dalam studi angka yang kemudian diikuti oleh Ghiyat al-Din alKashani sebagai seorang matematikawan muslim terkenal dalam bidang komputasi dan teori angka.

\title{
Kemajuan Sains Islam di Bidang Fisika dan Kimia
}

Kemajuan di bidang fisika dan kimia tidak lepas dari peranan Aristoteles sebagai orang yang memberikan konsep fisik sebagai gabungan antara materi dan forma. Walaupun pada akhirnya mayoritas umat muslim lebih condong terhadap aliran teologi dibandingkan Aristotelian (Nasr, 2001, p. 126). Beberapa umat muslim tetap mempertimbangkannya sebagai pemberi pengaruh besar pada pengetahuan tentang fisik. Sedangkan Islam dalam kimia sudah berkembang sejak masa kebangkitan Islam tepatnya pada abad ketujuh, dan puncaknya ada pada sosok Jabir Ibn Hayyan yang diakui pengaruhnya baik di Timur maupun di Barat. Dua keadaan ini tidak terlepas dari penerjemahan besar-besaran yang terjadi di Gudinshapur.

Kedua tradisi ini berkembang cukup pesat dan memberikan kontribusi berupa karya. Dalam tradisi kimia Jabir Ibn Hayyan sangat dipertimbangkan sebagai kimiawan Islam terkenal. Karyanya dalam berbagai bidang dikumpulkan dalam koleksi khusus (Jabirian Corpus). Selain itu Al-Razi pada tangannya proses-proses kimia dasar menjadi sangat tepat diungkap diantaranya: distilasi, kalsinasi, kritalisasi, evaporasi, dan filtrasi, al-Iraqi dijuluki sebagai kimiawan abad ketigabelas dengan karya gemilangnya The Cultivation of Gold. Dalam bidang fisika Alhazen (Ibn al-Haitham) memberikan kontribusi besar pada studi gerak dengan penemuannya mengenai prinsip inersia, dan pengetahuan statistik. Tak hanya itu, ia juga dapat mentransformasikannya ke dalam bidang optik, dan menjadikannya ilmu pengetahuan baru. Al-Birruni dicatat sebagai seorang fisikawan independen atas karya Aristoteles bahkan dalam beberapa aspek ia menjadi komentator pada konsep gerak, dan tempat. Komentarnya berujung pada solusi rasional, bahkan pada beberapa aspek menggunakan proses observasi. Al-Khazini meneruskan tradisi al-Birruni, ia ikut mengkritik karya Aristoteles dalam konsep gerak, dan mengembangkan konsep hidrostatik serta mekanik al-Birruni (Nasr, 2001, pp. 128, 244). 


\section{Kemajuan Sains Islam di Bidang Kedokteran}

Secara umum ciri khas kedokteran Islam adalah gabungan antara metode observatif empiris Hippocratic dengan metode filosofis Galen yang keduanya merupakan tokoh Yunani serta penambahan teori dari bangsa Persia dan India (Nasr, 2001, p. 188). Ini semua dilatarbelakangi oleh masyarakat serta ilmuan yang mencari perlindungan di Gudinshapur. Tempat ini dijadikan pusat pengetahuan Islam sekitar tahun 489 M khususnya di bidang kedokteran. Jatuhnya Antioch ke tangan Shapur serta penutupan sekolah Edessa oleh Kaisar Zeno membuat masyarakatnya pindah ke Godenshapur, sehingga mulai terjadinya transformasi budaya dari masing-masing bangsa. Kedua bangsa ini kemudian memberikan kontribusinya pada sains muslim di bidang kedokteran. Penutupan sekolah Athena oleh Kaisar Justinian juga menjadi cikal bakal transformasi budaya Yunani khususnya di bidang kedokteran, pasalnya para pakar di bidang kedokteran mencari perlindungan dan pengembangan ilmunya di Godenshapur yang dinilai sudah cukup berkembang di bidang tersebut. Tak lama kemudian terjadi penambahan pengetahuan di bidang kedokteran oleh tradisi India yang dibawa oleh Vizier Anushirwan sebagai seorang dokter India. Transformasi budaya dari beberapa bangsa ini menjadikan kedokteran Islam berkembang pesat dan menjadi pusat dari ilmu pengetahuan di bidang tersebut bagi bangsa Yunani, India dan Syiria (Selin, 2008, p. 1541).

Tokoh-tokoh dalam kedokteran Islam memberikan kontribusi yang besar bagi bangsa-bangsa setelahnya. Mereka ahli dalam hal tulis menulis dan menghasilkan karya-karya di bidang kedokteran. karya tersebut dimuat dalam ensiklopedia Tibb and Hikmah dan menjadi teks standar kedokteran untuk beberapa abad kemudian, bahkan diterjemahkan ke dalam berbagai bahasa dan menjadi basis bagi penemuan dalam bidang kedokteran.

Secara historis tokoh-tokoh berpengaruh tersebut antara lain: Ali Ibn Rabban Thabari dengan karyanya Paradise of Wisdom (Firadaus al-Hikmah) sekaligus menjadi guru dari al-Razi (Rhazes). Muridnya al-Razi menjadi seorang dokter terkemuka bahkan ia dipercaya untuk menjadi pemimpin di rumah sakit Baghdad, kontribusinya ada pada beberapa karyanya yang secara khusus memberikan deskripsi perbedaan antara chickenpox dengan smallpox serta deskripsi mendalam tentang campak. Al-Razi membuat sebuah karya berdasarkan observasi dan pengalamannya dengan judul alHawi. Karya ini merupakan sebuah ensiklopedia medis terkenal. Salinan karya ini diletakan di Bethesda Maryland serta dikategorikan sebagai manuskrip medis tertua di dunia hingga saat ini. Ibn Sina dikategorikan sebagai seorang dokter hebat. Kehebatan tersebut dibuktikan atas karya-karyanya yang berjumlah sekitar 100 karya dengan 16 kategori karya kedokteran serta Qonun fi l-tibb sebagai magnum opusnya dalam bidang ini. Dalam bidang khusus anatomi Ibn Nafis dikategorikan sebagai orang yang memberikan kontribusi besar. Ia menambahkan konsep baru yang merupakan revolusi dari konsep-konsep anatomi kuno dengan penemuannya terhadap sirkulasi paru-paru (Selin, 2008, pp. 1544-1545). Ali Ibn Isa (Jesu Haly) pada abad kesepuluh membuat risalah khusus tentang mata The Note Book of Occulist dan diikuti oleh buku yang berjudul Book of Selection on the Treatment of the Eye oleh Canamusali seorang dokter dari Mesir. Di abad keempatbelas al-Akhfani dan Sadaqah Ibn Ibrahim al-Shadhili menulis karya penting dalam bidang ophtamologi (studi mengenai mata). 
Pada abad kesebelas Abu al-Qasim al-Zahrawi menulis karya tentang bedah yang dimuat dalam Concession or Concessio dengan mengandalkan karya Paul of Aegina seorang dokter dari Yunani, namun ia menambahkan beberapa materi orisinil pada karyanya. Ibn Rusd (Averrous) yang sebelumnya dikategorikan sorang filosof membuat karya di bidang kedokteran dengan judul The Book on Generalities on Medicine. Kemudian Abu Mansur al-Muwaffaq membuat karya penting dalam bidang obat-obatan yang terangkum dalam karyanya Foundation of the True Properties of Remedies. Di tanah Persia Ismail Sharaf al-Din al-Jurjani membuat karya ensiklopedia medis penting yang berjudul Treasury Dedicated to the King of Khwarazm. Kemudian Quth al-Din Shirazi murid dari Nasir al-Din Tusi membuat komentar atas karya Conun fi al-Tib Ibn Sina dengan judul The Present to Sa'd (Nasr, 2001, pp. 213-217).

\section{PENUTUP}

Sejauh penjelasan historis diatas dapat disimpulkan bahwa paradigma holistik yang sebelumnya terdapat pada sains Islam dapat diterapkan pada sains modern. Namun hal ini dapat diterapkan pada arti sains di zaman modern, bukan pada arti sains yang berpandangan modernisme, karena secara historis sains yang ada pada suatu masa itu dapat berubah ubah atau bersifat tentatif baik secara potensial maupun aktual. Artinya sains pada hakikatnya tidak terikat oleh paradigm tertentu untuk bisa dikatakan sebagai sains. Potensi berubah ini yang membuat paradigma holistik dapat diterapkan pada sains modern dan secara historis penerapan paradigma ini pernah dibuktikan pada sains Islam pada Abad Pertengahan yang terbukti memiliki kemajuan pada berbagai bidang. Ini sehingga paradigma holistik sekalipun sains di zaman modern itu dapat diterapkan. Islam secara historis menerapkan paradigma tersebut dengan cara memahami sains sebagai salah satu alat untuk menjawab realitas alam semesta.

\section{REFERENSI}

Boas, M. (1962). The Scientific Renaissance, 1450-1630. New York: Harper \& Brother.

Capra, F. (1975). The Tao of Physic. Colorado: Shambala Publication.

Capra, F. (1996). The Web of Life. New York: Anchor Book.

Henry, J. (2003). The Scientific Revolution and The Origins of Modern Science. Houndmills: Palgrave.

Huff, T. E. (2003). The Rise of Early Modern Science. New York: Cambridge University Press.

Kenny, A. (2006). A New History of Western Philosophy. New York: Oxford University Press.

Maftukhin. (2010). Nuansa Studi Islam: Sebuah Pergulatan Pemikiran. Depok: Teras.

Nasr, S. H. (1989). Knowledge and the Sacred. New York: State University of New York Press.

Nasr, S. H. (1993). The Need for Sacred Science. Albany, NY: Curzon Press.

Nasr, S. H. (2001). Science and Civilization in Islam. Chicago: ABC International Group.

Nasr, S. H. (2007). The Essential Seyyed Hossein Nasr. Canada: World Wisdom Inc. 
Nasr, S. H. (2010). In Search of the Sacred. Colorado: Praeger.

Russel, B. (1945). History of Western Philosophy. New York: Simon \& Schuster.

Saliba, G. (1994). A History of Arabic Astronomy. New York: New York University Press.

Selin, H. (2008). Encyclopedia of the History of Science. New York: Springer.

Shirazi, S. al-M. (1999). Mazahir al-Ilahiyyah fi asrar al-Ulum al-Kamaliyyah. Tehran: Sadra Foundation of Islamic Philosophy.

Turner, H. R. (1995). Science in Medieval Islam. Austin: University of Texas Press. 